\title{
Archaeological Testing of Sites 41FY141, 41FY151, 41FY152, and 41FY153 Fayette County, Texas
}

\author{
Glenn T. Goode
}

Follow this and additional works at: https://scholarworks.sfasu.edu/ita

Part of the American Material Culture Commons, Archaeological Anthropology Commons, Environmental Studies Commons, Other American Studies Commons, Other Arts and Humanities Commons, Other History of Art, Architecture, and Archaeology Commons, and the United States History Commons

Tell us how this article helped you.

This Article is brought to you for free and open access by the Center for Regional Heritage Research at SFA ScholarWorks. It has been accepted for inclusion in Index of Texas Archaeology: Open Access Gray Literature from the Lone Star State by an authorized editor of SFA ScholarWorks. For more information, please contact cdsscholarworks@sfasu.edu. 


\section{Archaeological Testing of Sites 41FY141, 41FY151, 41FY152, and 41FY153 Fayette County, Texas}

\section{Licensing Statement}

This is a work produced for the Texas Department of Transportation (TxDOT) by the report producer. TXDOT and the report producer jointly own all rights, title, and interest in and to all intellectual property developed under TXDOT's contract with the report producer. The report may be cited and brief passages from this publication may be reproduced without permission provided that credit is given to both TXDOT and the report producer. Permission to reprint an entire chapter, section, figures or tables must be obtained in advance from either the Supervisor of the Archeological Studies Branch, Environmental Affairs Division, Texas Department of Transportation, 125 East 11th Street, Austin, Texas, 78701 or from the report producer. 
ARCHAEOLOGICAL TESTING OF SITES

41M141, 41FY 151， 41FY 152, AND 41FY153

FAYETTE COUNTY, TEXAS

B y

Glenn T. Goode

Tex as

State Department of Highways and Public Transportation

Highway Design Division

November 1983 


\begin{abstract}
Four prehistoric sites occurring within a one mile stretch of FM 153, ten miles northwest of LaGrange, Texas, were investigated in November, 1983. These sites were evidenced by light scatters of burned rock and lithic debris on the surface. Excavation revealed shallow sandy loam deposits containing very small amounts of cultural material. The portion of these sites within the FM 153 right-of-way have no potential for further work.
\end{abstract}




\section{INTRODUCTION}

Archaeological sites 41FY141, 41FY151, 41FY152, and 41FY153, were recorded during the survey of a Fayette Electric Cooperative power line (Laurens, Guy, and Prewitt 1979), and were recommended for testing (Fig. 1). During the period November 15 and 16, 1983, test excavation was conducted by Glenn T. Goode of the State Department of Highways and Public Transportation (SDHPT) Archaeology Section and three members of the local SDHPT office in LaGrange. Testing was performed in accordance with the Procedures for the Protection of Historic and Cultural Properties (36 CFR, Part 800), procedures prescribed and endorsed by the Federal Highway Administration. The testing objective was to determine eligibility for nomination to the National Register of Historic Places as prescribed by law. 
This Page Redacted Per THC Policy 
Testing involved the excavation of 1 by 1 meter excavation units, miscellaneous shovel tests, and auger tests. Excavation was done in arbitrary $10 \mathrm{~cm}$ increments, all matrix being screened through $1 / 4$ in. hardware cloth. Artifacts were placed in appropriately marked bags and examined; burned rock was recorded by weight and discarded. Excavation units were located relative to the FM 153 centerline and to the south right-of-way of the new project (Fig. 2 and 3). 


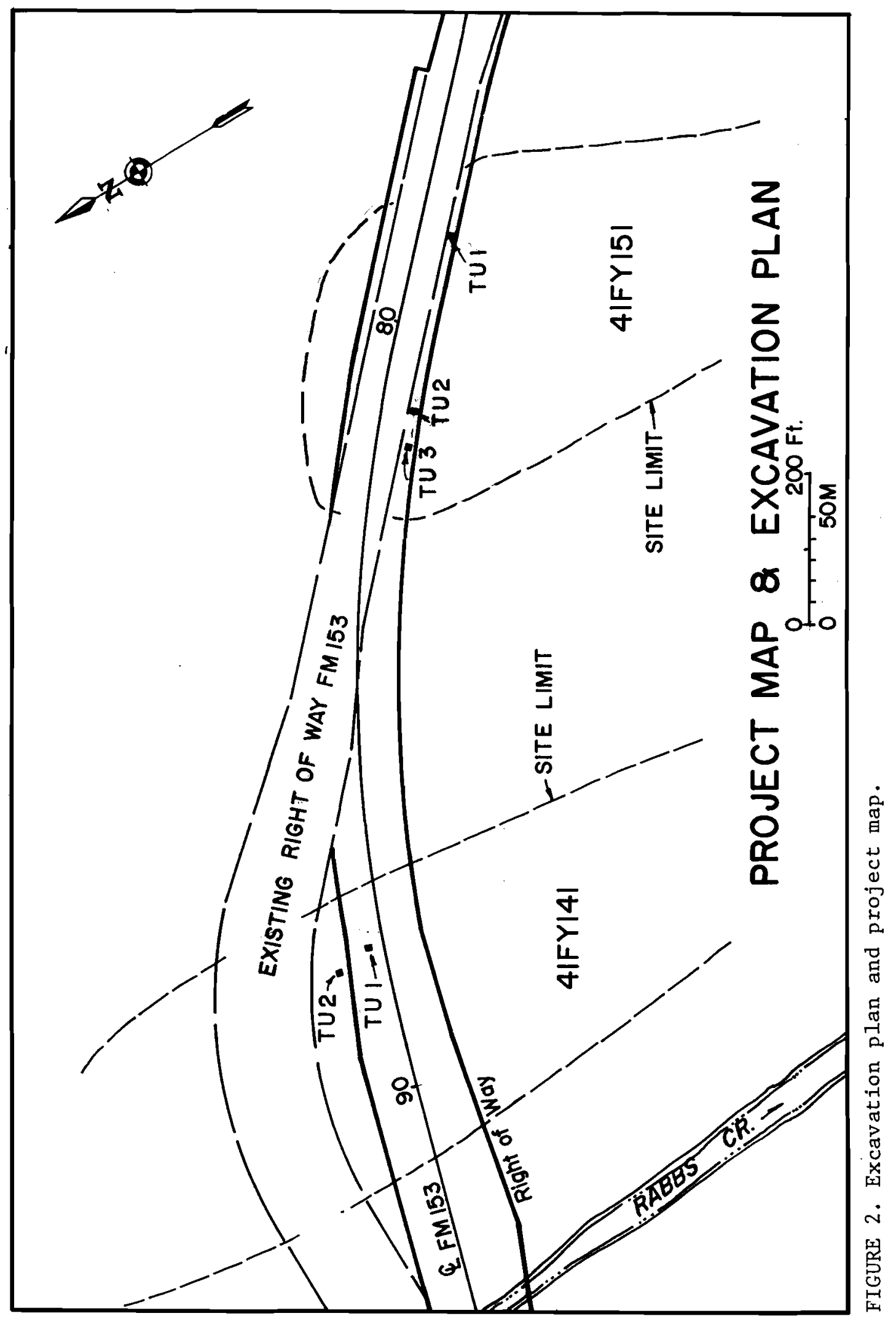




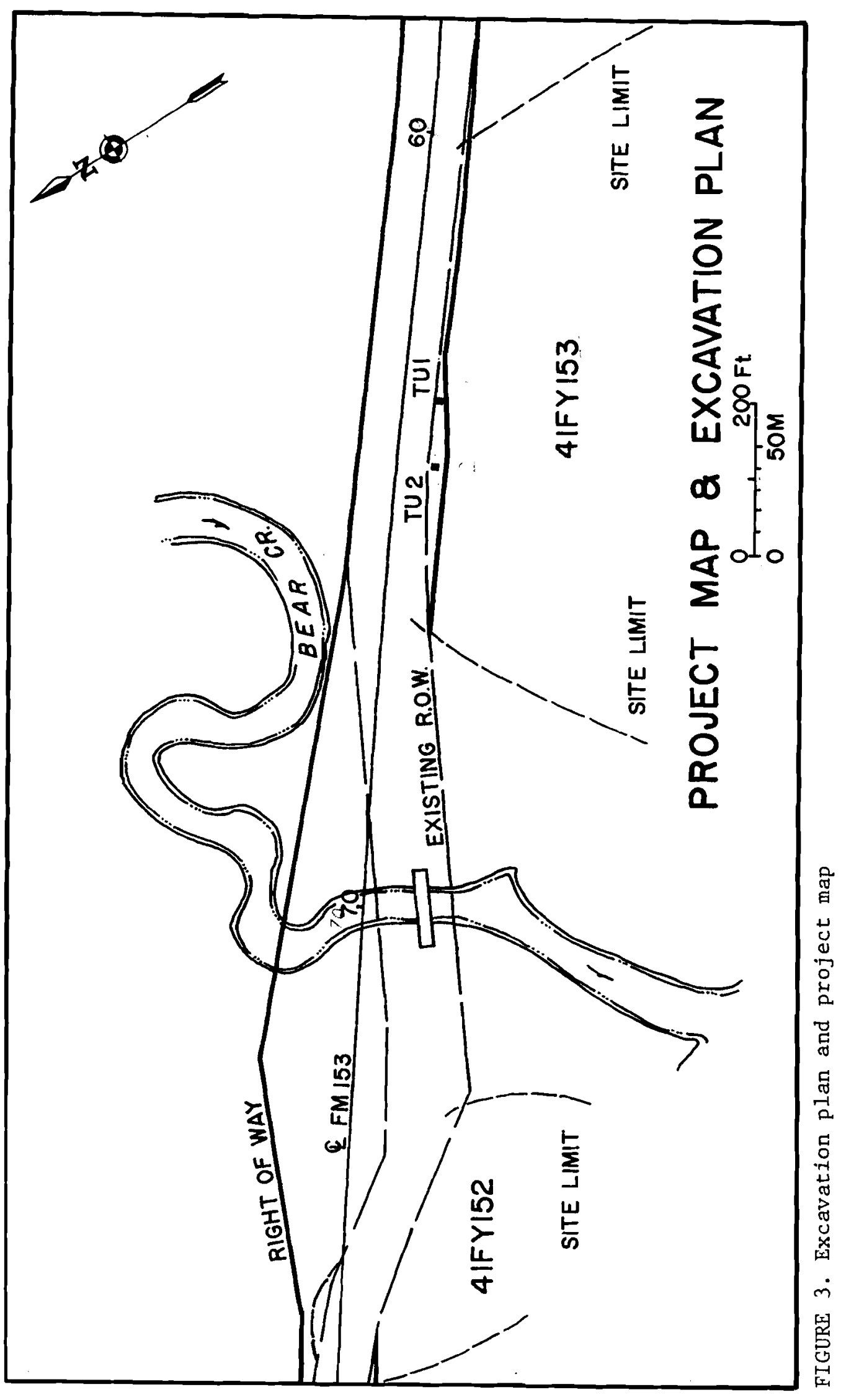


SITE $41 F Y 141$

This site is situated on a low, narrow rise, 80 meters wide, which begins about 30 meters east of Rabbs Creek. The northern end of the rise was removed by the present FM 153. To the south, the rise extends for more than 200 meters. From the northern side of the road, surface elevation drops gradually into a shallow depression, then rises gently to the general floodplain level. On this higher ground which extends to the creek bank, artifacts occur on the surface for at least 200 meters north. South of the road the burned rock and lithic debitage seen on the surface are rather sparse, widely separated, and scattered over an area of 50 by 100 meters. This evidence conflicts with the original survey which cites "a relatively dense concentration of burned rock and lithic debris." There are no "relatively dense concentrations," neither on the surface nor below. South of FM 153, all of the site is under cultivation and recent plowing has created deep furrows. Recent rains clearly exposed such materials as are present; there is no indication of artifact collecting since the rain.

Testing at this site produced almost nothing; a total of 3 miscellaneous flint flakes was found in the two 1 by 1 meter test units and several shovel tests. Therefore, an examination of surface material was necessary to gain an understanding of cultural activities.

Lithic material observed on the surface includes cores, flakes, 2 arrowpoint preform fragments, 1 arrowpoint distal fragment, and 1 thin biface fragment. The relative scarcity of these materials and the absence of diagnostic tools permits no definitive statement regarding site function and cultural affiliation. A majority of the lithic debitage is indicative of initial-stage cobble-reduction of quarrying. Ten cores examined show only limited reduction, indicating that flake, rather than biface production, was the primary strategy. 
Flakes are predominately hard-hammer, produced of primary and secondary origin, and are of relatively large size and/or thickness. A few interior/soft-hammer flakes indicate that complete biface reduction/ rejuvenation took place as well, but on a very limited scale. The observance of few interior flakes conflicts with the survey report of "many interior flakes." "Many interior flakes" were not present on the site during this investigation.

One trimmed-edge flake is a possible light scraping tool; no formally shaped unifaces were noted. Other tools or failures are the previously mentioned arrowpoint fragment/preforms and biface fragment. Of these materials, only the arropoint tip occurred within the right-of-way .

At least three major classes of tools are represented, although barely. From these, limited conclusions can be made about site activities and temporal placement. The three 'arrowpoint' fragments are the only diagnostic indicators recovered from the three floodplain sites. These, of course, indicate a Neo-American occupation, but their lack of distinguishing traits precludes an assignment to either the Austin or Toyah phase. The small (3 by $2 \mathrm{~cm}$ ), thin biface fragment may have been a small knife-form common in Neo-American assemblages. There is nothing distinctive about the trimmed flake.

Apparently, 41FY141 represents a Neo-American short-term habitation camp at which certain specialized activities were performed. The arrowpoints, biface, and trimmed flake indicate activities concerned with food procurement and preparation. Burned chert and quartzite, probable hearthstones, perhaps were involved in these activities as well. Lithic debitage indicates basic cobble/core reduction, predominately by hard-hammer percussion. Apparently this technology was directed more toward flake/tool production than toward biface production. It is likely that surface collection of artifacts has skewed the interpretation of this lithic material. 
Situated on two low knolls in the floodplain of Rabbs Creek, 41FY151 represents a minor lithic procurement and possible habitation site. FM 153 bisects the site, the greater portion lying south of the road toward a wide bend of Rabbs Creek. The entire site is under cultivation. The field was recently plowed forming deep furrows; subsequent rains clearly exposed the meager sample of artifactual material. The shallow soil profile containing artifacts is a $20 \mathrm{~cm}$ zone of sandy loam. This soil overlies a dense black clay loam which is culturally sterile. The soil profile is a duplicate of that a t 41FY141.

41FY151 is situated 150 to 200 meters east of 41FY141, the two sites being separated by a wide depression which is a possible relict stream channel. This depression extends past the west and south portions of the site to Rabbs Creek. To the north of FM 153 it continues across the broad floodplain. The depression is 3 to 4 meters lower than $41 F Y 141$ and 2 to 3 meters lower than 41FY151.

Cultural material observed on the surface consists of lithic debitage and burned rock. The lithic debitage consists of cores and flakes; no tools of any kind were noted. The cores are gravel cobbles showing a minor amount of reduction. There are no thoroughly reduced cores, bifacial cores, or initial stage bifaces. Flake debitage is predominately hard-hammer primary and secondary specimens of relatively large size (greater than 30 to $40 \mathrm{~mm}$ ). This debitage sample is quite similar to that of 41FY141, with the material total being perhaps slightly smaller.

Three 1 by 1 meter test units and several shovel tests constitute the excavation at 41FY151. One piece of 1 ithic debitage and several burned rock fragments are the cultural materials recovered. Apparently, examination of surface material would provide a better understanding of the site than would excavation. 
Sparse, widely separated burned rocks and lithic debitage mark the presence of this minor aboriginal site. Located on a low rise 25 meters from the west bank of Bear Creek, the site extends southward onto the floodplain of the larger Rabbs Creek, only 30 meters distant. The site extends north and west across FM 153 but is barely noticeable in this area. The soil profile is shallow sandy loam overlying clay loam--identical to sites $41 \mathrm{FY} 141$ and $41 \mathrm{FY} 151$.

The lithic debitage is quite similar to that of 41FY151, which is 150 to 200 meters west. These materials are of rather large size: the flakes are mostly larger than 30 to $40 \mathrm{~mm}$ and the cores are medium cobble size. Flakes are predominately hard-hammer produced and primary/secondary specimens are most numerous. This picture of the lithic technology duplicates that of the other floodplain sites, but on a smaller scale.

FM 153 improvements will not impact the major part of this site south of the road; therefore, no excavations were placed here. Several shovel tests north of FM 153 produced no cultural material.

Site $41 F Y 152$ appears to be a short-term lithic procurement/habitation site which was occupied very infrequently. 
SITE 41FY153

The small portion, 55 by 9 meters, of 41FY 153 occurring in the FM 153 right-of-way is about 125 meters northeast of the bluff/east bank of Bear and Rabbs creeks where the initial survey located the major concentration of this site. The site area investigated by this project is situated on a point of the broad upland terrace which extends just beyond the north right-of-way, then drops about two meters in elevation. No cultural material was observed on the north side of FM 153.

The site is covered with coastal bermuda grass and oats, obscuring most of the surface. Near FM 153, in the old right-of-way, cultural material is clearly visible on the surface. Burned rock and lithic debitage are moderately abundant in some areas. A slightly denser concentration of material exists here than at the floodplain sites.

Excavation at 41FY153 comprised two 1 by 1 meter units and several shovel and auger tests. The soil containing artifacts is loamy sand, light gray to darker gray brown in color, averaging $35 \mathrm{~cm}$ in depth in the two test units. Over the remainder of the test area the average depth is $20 \mathrm{~cm}$. Underlying the sand is a compact grayish to reddish brown clay which contains no artifacts.

Artifacts occurred throughout the sandy deposit, but in rather small numbers. Test Unit 1 produced 80 flakes and small amounts of burned rock in three levels. Test Unit 2 yielded 55 flakes, 1 core, and 1 biface distal section in four levels. Burned rock was present in small amounts. In the bottom level of both units an increase in burned rock was noted. This was not the case with artifacts, however.

Lithic debitage of 41FY153 differs considerably from the floodplain site assemblages. Here, specimens of small size constitute a large majority of the sample. Only a few flakes are larger than $30 \mathrm{~mm}$ and more than half of the total sample are interior flakes. A greater percentage of soft-hammer flakes is present, but hard-hammer specimens 
make up about $60 \%$ of the sample. One core was found in the excavation; none occurred on the surface. One biface distal section and one small flake with trimmed edges are the only possible tools in the sample. The biface distal fragment is a possible dart point fragment and the trimmed flake is possibly an arrowpoint preform. 


\section{SUMMARY AND RECOMMENDATIONS}

This project examined four prehistoric sites along the proposed new right-of-way of FM153 in northern Fayette County. Three of the sites occur on low rises of the Rabbs Creek floodplain. A tributary, Bear Creek, meets Rabbs Creek 100 to 500 meters east of these sites. The east bank of both streams is a steep bluff, the western edge of an upland terrace. Upon this terrace is located the fourth site, 41FY153. The initial survey recorded rather abundant cultural material along the terrace edge nearest the streams. This area is outside the right-of-way and was not investigated.

Findings from the test excavations were extremely meager. However, limited information relevant to settlement pattern studies can be inferred from examination of floodplain site surface materials.

Only the upland terrace site, 41EY153, produced a substantial sample from excavation.

The presence of the three floodplain sites near the now deeply entrenched streams might indicate that they are of relatively recent age. Meander scars across the floodplain attest to the streams' past active nature. Site $41 F Y 141$ produced the only "diagnostic" material of the floodplain sites, arrowpoint fragments also indicating a recent age.

Site 41FY141 has somewhat more material, and in greater variety, but lithic debitage at the three sites is essentially identical. This material is primarily representative of initial stage cobble reduction/flake production. Limited tool production is also inferred from the minute sample of soft-hammer and/or interior flakes. Tool production is more obvious at 41FY141 with preforms and a flake tool.

The widespread but lightly concentrated nature of the cultural refuse, including burned rock, indicates short-term and very sporadic occupation, 
possibly only within late prehistoric times. The sites could be classified as "light scatters without features" (Robinson 1982) according to a settlement pattern model for Fayette County. The limited evidence indicates that the floodplain sites are habitation sites--areas at which small groups of people camped, collected flint cobbles and manufactured tools, engaged in hunting and probably a variety of subsistence-related activities.

The portion of the terrace site subject to this investigation is apparently a habitation site as well. A larger sample, though still relatively small, of cultural debris was found in this excavation. Unfortunately, the greater amount of material is no more informative than the lesser amount of the floodplain sites. Longer periods of occupation and, almost certainly, occupation over a much greater span of time are indicated by the findings, by the large area of occupation, and by the favorable location. One possible dart point fragment and a small trimmed flake, a possible arrowpoint preform, are the only indicators of cultural affiliation. Undoubtedly, Neo-American remains exist at this site, and probably Archaic remains as well.

The investigated portion of $41 F Y 153$ and the entirety of the floodplain sites hold extremely low potential for contributing to the prehistoric record. In view of this assessment, sites 41FY141, 41FY151, 41FY152, and 41FY 153 are considered unworthy of further investigation and of inclusion in the National Register of Historic Places. 


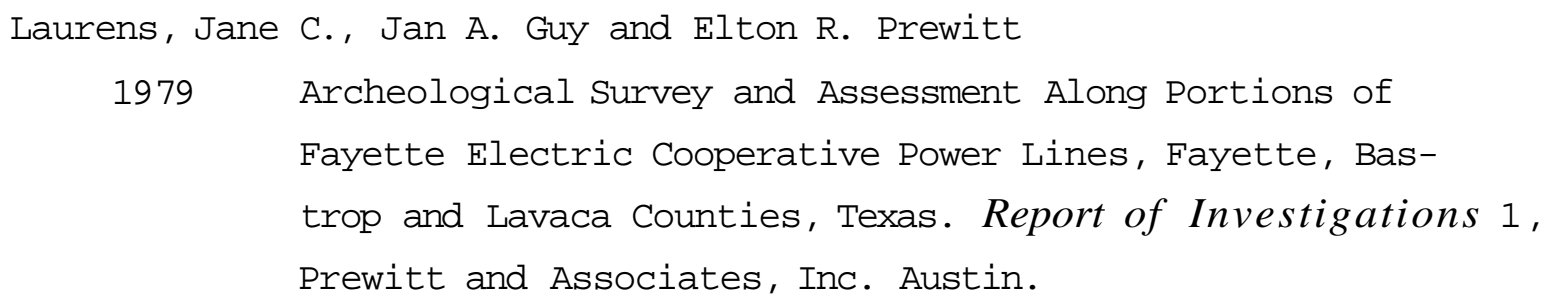

Robinson, David G.

1982 A Cultural Resource Survey of the Fayette to Salem Transmission Corridor, Fayette, Austin and Washington Counties, Texas. Texas Archeological Society Technical Bulletin 60, The University of Texas at Austin. 